\title{
The New Temple
}

\section{On the origin, nature and composition of the partes Digestorum}

\author{
W.J. Zwalve \\ Radboud Universiteit Nijmegen; Faculteit Rechtsgeleerdheid, Afdeling \\ Rechtsgeschiedenis; Universiteit Leiden; Faculteit der Rechtsgeleerdheid, \\ Afdeling Rechtsgeschiedenis, Postbus 9520, 2300 RA Leiden \\ wjzwalve49@gmail.com \\ Th. de Vries \\ Department of Research Methodology, Measurement and Data Analysis, \\ Universiteit Twente, Drienerloolaan 5, 7522 NB Enschede \\ tdevries@wxs.nl
}

\section{Summary}

The present article purports to stress the importance of the legal curriculum in the overall compilation process of Justinian's Digest. The basic hypothesis is that, in composing the Digest, Justinian's drafting committee based its composition on the arrangement of the legal curriculum as it was before Justinian and as it was about to be changed in the process. The basis of this hypothesis is the division of the Digest into seven partes. It is contended that the basic structure of the first five partes of the Digest was predetermined by the legal curriculum, whereas the last two partes are an 'Appendix Masse'. It is also contended that the distribution of books over all the seven partes of the Digest is the result of a preconceived formula inspired by the mathematics of Diophantus of Alexandria.

\section{Keywords}

Justinian's Digest - legal curriculum - partes Digestorum - numerology - linear Diophantine equation 


\section{Introduction}

In the Orthodox Church, December 16 is the feast day of the prophet St. Haggai, who, after the return of the Jewish people from its Babylonian captivity, urged it to rebuild the Temple in Jerusalem. So it was no coincidence that the emperor Justinian chose the feast day of St. Haggai to consecrate his own new temple, for it was on the 16 th of December 533 that he promulgated the most important part of his prestigious legislative program, the Digest, 'proprium et sanctissimum templum iustitiae'1. Ever since the publication of Friedrich Bluhme's seminal article on the sequence of fragments in the titles of the Digest $^{2}$, quite a lot has been written on the composition of the Digest, most of it on the basis of Bluhme's conclusions ${ }^{3}$. Without venturing to enter into an outright criticism of the increasingly complex (and sometimes even mindbaffling) ${ }^{4}$ theories extending and refining Bluhme's findings ${ }^{5}$, the present article purports to stress the importance of the legal curriculum in the over-all compilation process ${ }^{6}$. The basic hypothesis is that, in composing the Digest,

1 Const. Deo auctore $\S 5$. See for the metaphor of the Digest as a templum iustitiae also Const. Tanta $§ 2$.

2 F. Bluhme, Die Ordnung der Fragmente in den Pandectentiteln, Ein Beitrag zur Entstehungsgeschichte der Pandecten, Zeitschrift für geschichtliche Rechtswissenschaft, 4 (1820), p. 257-472.

3 There is a good survey of the pre-1972 literature in F. Wieacker, Zur Technik der Kompilatoren, Prämissen und Hypothesen, sz 89 (1972), p. 293-323. For a survey of later literature see W. Kaiser, Digestenentstehung und Digestenüberlieferung, Zur neueren Forschung über die Bluhme'schen Masse und der Neuausgabe des Codex Florentinus, sz 108 (1991), p. 330-350 and T. Honoré, Justinian's Digest, Character and Compilation), Oxford 2010, p. 8-10.

4 P.J. Furlong, Justinian and Mathematics, An Analysis of the Digest's Compilation Plan, Australian Journal of Legal History, 9 (2005), p. 85-117.

5 See T. Honoré, How the Digest Commissioners worked, sz 87 (1970), p. 246-314 and his other articles, mentioned in his Justinian's Digest, p. 8 n. 3, all of them conceived as extensions and refinements of Bluhme's findings; for a rebuttal of Honorés assumptions see D. Osler, The Compilation of Justinian's Digest, sZ 102 (1985), p. 129-184. For extensions and refinements of Bluhme see also D. Mantovani, Digesto e masse bluhmiane, Milan 1987.

6 To avoid misconceptions, I should stress that this article is not intended as a criticism 'Hofmann-style' of Bluhme and his article (F. Hofmann, Die Compilation der Digesten, Vienna 1900 , let alone of modern Bluhme-inspired literature, such as the above mentioned. There is one thing, however, that should be called attention to. Bluhme was a very careful scholar, as is clear from the title of his famous article:Die Ordnung derFragmente in denPandectentiteln . He did not write an article on the Ordnung derDigesten, which is quite another thing. There is no compelling relation between the arrangement of fragments within the titles of each book and the arrangement of the books of the Digest itself, since the latter have another causa finalis than the former. I should add, furthermore, that ever since Mommsen's scathing remarks on Hofmann's posthumously published book (Hofmann versus Blume, sz 22 (1901), p. 1-11) it has 
Justinian's drafting committee based its composition on the arrangement of the legal curriculum as it was before Justinian and as it was about to be changed in the process, since a new legal curriculum was to be introduced at the same time as the publication of the Digest. The basis of this hypothesis is the division of the Digest into partes, a division derived from educational practices current long before the introduction of Justinian's legislative program. Consequently, we must have a close look at the old legal curriculum 7 . In doing so, I do not purport to present a new look at that curriculum, which is quite familiar to (some) legal historians, but to emphasize and to support the fact that it served as the model for the composition of the Digest.

\section{The old curriculum}

On the very same day the Digest was promulgated, Justinian sent a letter, containing detailed instructions on the way the new legislation was to be taught, to the law professors of the imperial law schools in Constantinople and Beirut, the so-called Const. Omnem. It also contains a short description of the old curriculum allowing for the following reconstruction ${ }^{8}$.

The contents of the curriculum in the first year are somewhat problematic since Justinian (or rather Tribonian) speaks of it as follows:

nihil aliud nisi sex tantummodo libros et ipsos confusos et iura utilia in se perraro habentes a voce magistra studiosi accipiebant, ceteris iam desuetis, iam omnibus inviis. in his autem sex libris Gaii nostri institutiones et libri singulares quattuor, primus de illa vetere re uxoria, secundus de tutelis et tertius nec non quartus de testamentis et legatis connumerabantur ${ }^{9}$.

not received the serious attention it should have had. As will be seen further on in the text, I even share some of its conclusions, though on different grounds.

7 On pre-Justinian law teachers and their curriculum see: C.G.E. Heimbach, Basilicorum Libri LX Prolegomena, ed. Amsterdam 1962 (with an introduction by H.J. Scheltema), p. 2-3; 8-11 and H.J. Scheltema, L'enseignement de droit des antécesseurs, Leiden 1970, p. 7-9 (now also in: N. van der Wal, J.H.A. Lokin e.a. (edd.), H.J. Scheltema, Opera minora ad iuris historiam pertinentia, Groningen 2004, p. 64-65). See also J.-A.-B. Mortreuil, Histoire du Droit Byzantin, I, Paris 1843, p. 257-273; P. Collinet, Histoire de l'école de droit de Beyrouth, Paris 1925, p. 223-240; N. van der Wal and J.H.A. Lokin, Historiae iuris graeco-romani delineatio, Groningen 1985, p. 20-24 and D. Liebs, Juristenausbildung in der Spätantike, in: Ch. Baldus, Th. Finkenauer and Th. Rüfner (edd.), Juristenausbildung in Europa zwischen Tradition und Reform, Tübingen 2008, 31-45.

8 Const. Omnem $§ 1$.

9 Const. Omnem $\S 1$. 
We learn from this that the law professors read six 'books' in the first year of the curriculum. As a matter of course, the Institutiones of Gaius ('Gaius noster'), composed of four books, were read in the first year. Justinian mentions four additional libri singulares ('monographs'): one De re uxoria, one De tutelis and a third and a fourth De testamentis and De legatis, leaving us with a considerable conundrum, since four libri singulares plus the four books of Gaius's Institutiones makes eight books to be read, rather than six. Probably only two books from Gaius's Institutiones were actually read ${ }^{10}$. Since we know from Justinian himself that in the teaching of all these books much was left out as being superfluous ${ }^{11}$, it seems highly probable that the entire fourth book of Gaius was passed over since the Roman law of civil procedure (the subject of that book) had fundamentally changed since Gaius's time. It is, indeed, entirely missing in the fifth-century Epitome Gai and was also left out of Justinian's Institutes as well, forcing the compilers of Justinian's Institutes (Theophilus and Dorotheus) to compose the fourth book as a continuation of the third book of Justinian's Institutes, a continuation, that is, of the law of obligations.

There can be little doubt, however, about the nature of the four libri singulares (De re uxoria, De tutelis, De testamentis and De legatis) Justinian refers to in Const. Omnem $\S 1$, since we happen to have fragments of a pre-Justinian lecture on two of these libri singulares in the Scholia Sinaitica.

The so-called Scholia Sinaitica ${ }^{12}$ are papyrus membra disiecta, re-used as a book cover, found by the Greek scholar G. Bernardakis in the library of St Catherine monastery near Mount Sinai. They were first edited by R. Dareste, based on a copy of the fragments sent to him by Bernardakis. It was the second editor of the fragments, Karl Eduard Zachariae von Lingenthal, who identified them as parts of a commentary on Ulpian's libri ad Sabinum, a conclusion shared by Paul Krüger, who edited the fragments again on the basis of a reexamination of Bernardakis's copy and in contact with that Greek scholar ${ }^{13}$. It is this edition that is the basis of modern editions, as in FIRA. Since the Scholia contain references to the Codex Theodosianus and not to Justinian's Codex, it follows that

This passage from Omnem has initiated an old controversy, starting from the Gl. Sex tantummodo on Const. Omnem § 1 ('sed qui erant isti sex?'). Since it is immaterial to my present purposes, I will not go into it. For the hypothesis that only two out of the four books of Gaius's Institutiones were read, see also Schulz, Roman Legal Science, Oxford 1946, p. 275 .

11 Const. Omnem, § 1: 'multas partes eorum quasi supervacuas praeteribant'.

12 I have used the edition as published in FIRA II, Florence 1968, p. 637-652. See on the Scholia Sinaitica L. Wenger, Die Quellen des römischen Rechts, Vienna 1953, p. 550-551. the earlier editions by Dareste and Zachariae. 
they have been composed between 438 and 529 . Their origin from legal education is obvious, since they contain frequent exhortations to students, like 'notice that (etc.)' $(\sigma \eta \mu \varepsilon i \omega \sigma \alpha l \text { ö } \tau l(\varkappa . \tau . \lambda .))^{14}$, and 'learn that (etc.)' $(\mu \dot{\alpha} \vartheta \varepsilon \text { ö } \tau l(\varkappa . \tau . \lambda .))^{15}$. The fragments cover small parts of books $35-38$ of Ulpian's commentary ad Sabinum, dealing with two subjects, dos and tutela.

The subjects dealt with in the Scholia Sinaitica belong to the first year of the old legal curriculum, as Justinian has it in Const. Omnem $\S 1$. The four libri singulares he mentions there are typical of the 'Sabinian system'. Consequently, it seems fairly certain that, in the old curriculum, four parts (De re uxoria, De tutelis, De testamentis and De legatis) of Ulpian's libri ad Sabinum were read in the first year, in addition to readings from Gaius's Institutiones ${ }^{16}$. Justinian's statement that none of these books (including Gaius) was read in its entirety (per consequentias), but that many parts of it were passed over ${ }^{17}$, is confirmed by the Sch. Sinaitica, since there are, even in this small part on Ulpian's commentary covered by the Sch. Sinaitica alone, no less than five instructions to students to pass over certain sections of it ('Pass over (etc.)' $\left(\Delta i \varepsilon \lambda \vartheta_{\varepsilon}\left(\chi_{*} \tau . \lambda .\right)\right)^{18}$. There are two other aspects of the Sch. Sinaitica that should be emphasized. Firstly, the Sch. Sinaitica are comments in the Greek language to a text the students to which they are addressed are supposed to have before them in its original Latin version, as the references to the basic Latin text commented on clearly show ${ }^{19}$. Secondly, and more importantly, the fact that Ulpian's libri ad Sabinum are the basic textbook commented on. There are frequent references to the writings of other lawyers in the Sch. Sinaitica, Paulus prominently among them ${ }^{20}$, but these are mere references. The writings of these other lawyers were not the subject of the lectures: that was Ulpian's commentary ad Sabinum. Nevertheless, mere references though they may be, these allegations of other classical authors are important. They provide evidence that the books of these authors were not only available to the teachers themselves, but to students as well, since the references are very accurate and detailed, indicating, as they sometimes do, book, title and even the line where the passage referred to

\footnotetext{
14 For this see $S c h$. Sin. V,9 and 11; IX,23; X,27; XII,33; XIII,35; XIV,36.

15 Sch. Sin. V,9 and IX,23.

16 Liebs, Juristenausbildung in der Spätantike (supra, n. 7), p. 31-45 (34-35), concurs with the view presented here.

17 Const. Omnem $\S 1$ : '(...) quos nec totos per consequentias accipiebant, sed multas partes eorum quasi supervacuas praeteribant'.

18 Sch. Sin. XII,34; XVI,43 and 44; XVII,47; XVIII,49.

19 See Sch. Sin. IV,6 (ảpXj $\tau \hat{\omega} v$ ' $p \eta \tau \hat{\omega} v$ de die pone[enda]) and spectacularly so in XVI,43:

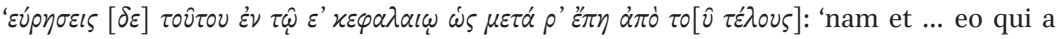
furioso'. See also infra, n. 21. 
is to be found ${ }^{21}$, strongly (if not conclusively) suggesting that these books were readily available (in the library of the Faculty of Law?) in standardized manuscripts at that time. The existence of standardized manuscripts of the writings of some classical Roman legal authorities, such as Paulus and Modestinus, at the time is consistent, since the lectures reported in the Sch. Sinaitica were given after the promulgation of the Codex Theodosianus (438) and consequently had to take account of the Lex citandi (C.Th. 1,4,3 (426)).

The first provision of the Lex citandi attributes the same auctoritas to the writings of Gaius as was credited to the writings of Papinian, Paul, Ulpian and Modestinus $^{22}$. It is the second provision of the Lex citandi, dealing with the auctoritas of other authors than the five just mentioned, which becomes important in our context:

Eorum quoque scientiam, quorum tractatus atque sententias praedicti omnes suis operibus miscuerunt, ratam esse censemus, ut Scaevolae, Sabini, Iuliani atque Marcelli omniumque, quos illi celebrarunt, si tamen eorum libri propter antiquitatis incertum codicum collatione firmentur.

It is clear from this provision that the authority of writers preceding the quinqueviri depended on the fact whether their writings were mentioned as books of authority in the writings of the quinqueviri. If so, they could be cited in court as books of authority, provided their opinions could be ascertained as such by a comparison of manuscripts since, says the Lex citandi, their contents were uncertain because of their antiquity. Given the authority attributed to the writings of the quinqueviri, it seems fairly reasonable to surmise that standardized copies of at least their writings were available; citations from older writers must have been very rare, since they could only be succesfully brought before the court if at least two copies were available at the same time, allowing for a comparison of manuscripts. Looking for references to other jurists in the $S c h$. Sinaitica, one finds nine references: five references to writings by Paul ${ }^{23}$; two

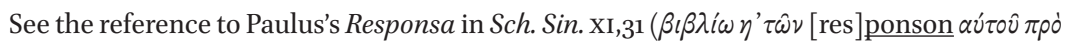

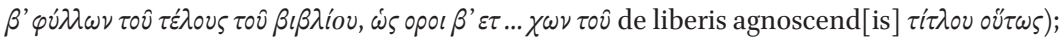
to Florentinus's Institutiones in XIII,35 ( $\beta \iota \beta \lambda i \omega \gamma^{\prime}, \tau \hat{\omega} \nu$ institionon $\alpha \dot{v} \tau o \hat{v} \pi \varepsilon \rho i \tau \dot{\alpha} \tau \dot{\lambda} \lambda \eta \tau 0 \hat{v}$

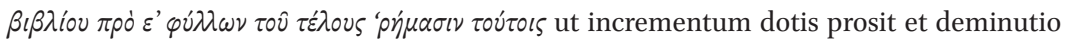
noceat) and (also in XIII,35) to Modestinus's liber primus Regularum ' $\pi \rho \dot{~} \iota \zeta$ regulas $\tau 0 \hat{0}$

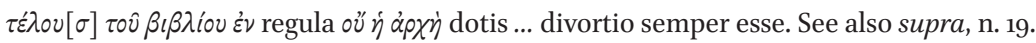
Gaium quae Paulum, Ulpianum et ceteros comitetur auctoritas lectionesque ex omni eius corpore recitentur'. 
references to Modestinus ${ }^{24}$; a reference to Marcianus's book ad formulam hypothecariam $^{25}$ and a reference to the Institutiones of Florentinus ${ }^{26}$. As a matter of course, this relatively small collection of comments on Ulpian's libri ad Sabinum we know as the Scholia Sinaitica cannot stand as a representative sample of the whole course, of which this is but a small part, but, nevertheless, the frequent reference to Paul, even within this short section, is striking. Ulpian's libri ad Sabinum is the text commented on; Paul and Modestinus belonged to the group of five jurists canonized by the Lex citandi. This leaves two references to jurists not belonging to the distinguished group of quinqueviri: Marcianus and Florentinus. Marcianus was a contemporary of Ulpian and Paul; Florentinus may have been somewhat (but not much) older ${ }^{27}$. Writings by these two lawyers could be cited in court as prima facie evidence on the state of the law only if they were mentioned by one of the quinqueviri, which is indeed the case for Marcianus ${ }^{28}$. Florentinus may have been cited by one of the quinqueviri as well, but I found no trace of that in the Digest.

The Sch. Sinaitica confirm a tradition among law professors after 426 (the date of the Lex citandi), but most likely established long before that, to base their lectures on the ius civile not on Sabinus directly, but on Ulpian's commentary ad Sabinum. But out of the fifty-one books of Ulpianus's massive commentary, only four subjects - de testamentis (Ulp. ad Sabinum, Books 1-14); de legatis (Ulp. ad Sabinum, Books 15-25); de re uxoria (Ulp. ad Sabinum, Books 31-36) and de tutelis (Ulp. ad Sabinum, Books 36-40) - were actually read by the pre-Justinian law professors ${ }^{29}$. Each of these four subjects was conveniently specified as a 'monograph' (liber singularis), consisting of a varying number of books from

timo ad Sabinum); XI,31 (Paulus, libro octavo Responsorum); XII,34 (Paulus, libro septimo ad Sabinum) and XIII,35 (Paulus, libro quinto ad Sabinum).

24 Scholia Sinaitica VI,12 (Modestinus, libro secundo Differentiarum) and XIII,35 (Modestinus, libro primo Regularum).

25 Scholia Sinaitica v,11.

26 Scholia Sinaitica XIII,35.

27 W. Kunkel, Herkunft und soziale Stellung der römischen Juristen, Graz-Vienna-Cologne 1967 (2nd ed.), p. 217 and 258.

28 Marcianus is cited by Ulpian in D. 28,1,15 and (probably) by Paul in D. 7,9,8. His authority is confirmed by a reference to Marcianus by Justinian himself in C. 8,47,10pr.

29 Some of the pre-Justinian law-professors are known by name, since some of the first commentators of Justinian's Corpus Iuris mention them as having been their teachers. We have five names: Cyrillus, Domninus, Patricius, Eudoxius and Demosthenes. See on these pre-Justinian law teachers: J-A.-B. Mortreuil, Histoire du Droit Byzantin, I, p. 257-273; Heimbach, Prolegomena (supra, n. 7), p. 8-11; P. Collinet, Histoire de l'école de droit de Beyrouth (supra, n. 7), p. 130-156 and H.J. Scheltema, Opmerkingen over Grieksche bewerkingen van Latijnsche juridische bronnen, Zwolle 1940, p. 6-10 (Opera minora, p. 191-194). On law teaching in late antiquity before Justinian generally see: N. van der Wal and J.H.A. 
the original of Ulpian's libri ad Sabinum, 36 for all of them together, a significant number as we shall see presently.

The four 'monographs' singled out of Ulpianus's libri ad Sabinum and read in the first year were the only more or less systematic approach in the old curriculum at the study of the old Roman ius civile, in classical times traditionally studied on the basis of the libri tres iuris civilis of Masurius Sabinus. The second and third year of the old curriculum were largely devoted to the study of the ius honorarium, based, again, on a commentary by Ulpian, this time his libri ad edictum, since the so-called partes legum Justinian refers to in Const. Omnem ${ }^{30}$ are to be identified with the partes of that commentary. The Sch. Sinaitica may serve to prove this point too. They contain a reference to a subject also explained by the teacher ${ }^{31}$ in his comments on the title 'de in integrum restitutione' $\tau \hat{\omega} \nu \alpha^{\prime}$ Ulpiani ${ }^{32}$, meaning the prima pars, or, as it is usually called, $\tau \dot{\alpha}$ $\pi \rho \hat{\omega} \tau \alpha^{33}$, of Ulpian's commentary ad edictum. There are some other references to Ulpian's commentary ad edictum being divided into partes as well. Papyrus PSI 14, no $1449^{34}$ contains a fragment from Ulpian's commentary ad edictum (liber 32). It predates Justinian's Digest and has some glosses in Greek. In one of these, to the sentence 'de Aquilia quid sentiamus alio commentario tradidimus' in Ulpian's text ${ }^{35}$, the reader is referred to '[ $[\bar{\varepsilon}] \nu \tau \hat{\omega}$ Aquilio $\tau \hat{\omega} \nu$ de iudiciis' ${ }^{36}$. I conclude from all this that Ulpian's commentary ad edictum was indeed the basis of the readings ad edictum in the second and third year of the curricu$\operatorname{lum}^{37}$ and that this book was for educational purposes conveniently divided

Lokin, Historiae iuris graeco-romani delineatio (supra, n. 7), p. 20-24 and D. Liebs, Juristenausbildung in der Spätantike (supra, n. 7), p. 31-45.

Const. Omnem § 2: 'prima pars legum ... tam ex illa parte legum, quae de iudiciis nuncupatur ... quam ex illa quae de rebus appellatur'.

The teacher is only indicated here, as elsewhere in the Sch. Sinaitica, by the abbreviation 'Sab.'. One of the earlier editors of the Scholia, Zachariae, identified him with a certain Sabatius, mentioned in Nov. 35 as someone who had been of service to Tribonian 'in legum confectione'. The suggestion was rejected by Krüger (Die Sinai-Scholien (supra, n. 13), p. 30(5)). It remains an attractive suggestion, though.

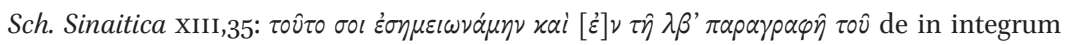
restitutione $\tau \hat{\omega} \nu$ a'Ulpiani.

For this see Const. Tanta § 2: 'prima pars, quae Graeco vocabulo $\pi \rho \omega \tau \tau \alpha$ nuncupatur'.

34 V. Bartoletti (ed.), Papyri Greci è Latini, vol. 14, Florence 1957, p. 159-170 (Arangio-Ruiz).

35 It can be traced to the Digest: D. 19,2,13,4 (Ulpianus, libro trigesimo secundo ad edictum). The (minor) changes by Justinian's compilators are interesting.

36 The reference is to the 18th book of Ulpian's commentary ad edictum (see D. 9,2,5,3).

37 See also A. Soubie, Recherches sur les origines des rubriques du Digeste, Tarbes 1960, 48: 'les libri ad edictum d'Ulpien constituaient officiellement l'objet de l'enseignement préjustinien'. 
into three partes, Ta Próta (1-14), De iudiciis (15-25) and De rebus (26-32) ${ }^{38}$, meaning that students did not read all 83 books of it, but only 32 . The division of these 32 books into three partes may be easily explained by referring to what has just been said about the presence of standardized manuscripts of the classical authors for educational purposes ${ }^{39}$. We may safely assume that the basic textbook, Ulpian's libri ad edictum, was available in a standardized edition as well. If so, it explains the division of Ulpian's libri ad edictum that were read in the law school into three standardized partes. As we have just seen, Ulpian's libri ad edictum were read over two consecutive years, the second and third year of the curriculum. Purchasing all 32 books to be read during this period at the same time (let alone all 82 books of the original) must have been prohibitively expensive for a student who had no need for all of them at once, but only for the sections that were read in class during a particular season. Unfortunately, we are not precisely informed about the customary seasonal breaks of these classes. There was the traditional vacation of some months during the summer (feriae vindemiales) ${ }^{40}$, but the great Christian holy days of Christmas and Easter must also have marked breaks in the schedule. Probably the division of Ulpian's libri ad edictum into three partes corresponded with these breaks in the legal curriculum.

Readings of the Prima pars ( $\tau \dot{\alpha} \pi \rho \omega \tau \tau \alpha$ ), and the partes De iudiciis and De rebus were spread over the second and third year of the pre-Justinian curriculum. What was left of the third year after they had been concluded was filled with readings from Papinian's Respons $a^{41}$. Accordingly, students in their third year were called 'Papinianistae' 42 , whereas in their second year they bore the name 'Edictales', since they started readings ad edictum in that year ${ }^{43}$. Justinian reminds the addressees of Const. Omnem that only eight out of the 19 books of the Responsa Papiniani were actually read to students and even those only imperfectly, so that they finished them still 'thirsting for knowledge'44, only to be left to themselves in their fourth year, when private reading from Paul's $R e$ -

38 See Justinian's reference to the seven books of the old pars De rebus in Const. Omnem $\S 1$.

$39 \quad$ Supra at n. 21.

40 Augustinus, Confessiones 9,2.

41 Const. Omnem $\S 1$ : 'in tertio autem anno quod ex utroque volumine, id est de rebus vel de iudiciis, in secundo anno non erat traditum, accipiebant secundum vicissitudinem utriusque voluminis: et ad sublimissimum Papinianum eiusque responsa iter eis aperiebatur'.

42 Const. Omnem $\S 4$.

43 Const. Omnem $\S 3$.

44 Const. Omnem $\S 1$ i: 'ut adhuc sitientes ab eis recederent'. 
sponsa was on the curriculum ${ }^{45}$ and the students were given the name ' $\lambda \dot{v} \tau \alpha$ ' ('problemsolvers') ${ }^{46}$. The readings from Paulus's Responsa closed four years devoted to the study of the writings of the classical Roman jurists ${ }^{47}$ on the basis, that is, of Ulpian's two commentaries, ad Sabinum and ad edictum. It was to be followed by a one-year course on imperial legislation (constitutiones), taken from the Codex Theodosianus and the private collections of the Codices Gregorianus and Hermogenianus. As we know from the Scholia Sinaitica, all three of these were already familiar to students from the frequent references to imperial legislation in the readings by their professors on Ulpian's libri ad Sabinum and ad edictum.

In as far as the writings of the classical writers are concerned, the old curriculum may be summarized as follows: leaving aside the introductory course on Gaius's Institutiones, it consisted of four components: a pars Sabiniana (readings from Ulpian's ad Sabinum, consisting of four 'monographs' (libri singulares)), a pars edictalis (readings from Ulpian's ad edictum, conveniently subdivided into three partes (Prima pars, De iudiciis and De rebus)), a pars Papiniana (readings from Papinian's Responsa) and a pars Pauliana, all of them to be read in four years, since the fifth year of the old curriculum was reserved for the reading of imperial legislation. The entire old curriculum is shown in table 1.

There is, throughout Const. Omnem, a hint of a certain underestimation of Paulus and his work, probably originating in the prevailing academic tradition to single out Ulpian's commentaries ad Sabinum and ad edictum, rather than Paulus's commentaries, as more suitable for educational purposes. The traditional selection of pieces to be read from Paulus's Responsa in the fourth year of the old curriculum was, says Justinian, badly chosen ${ }^{48}$, whereas, later on in Omnem, he even questions the wisdom of Paulus in spite of calling that lawyer prudentissimus ${ }^{49}$. This may explain why Paulus's name, unlike that of Papinian, was not to return prominently in the new Justinian curriculum as eponymous of an entire section of that curriculum. Prominent as Paulus and his work were still to be in the Digest, he was not assigned a special place in the

45 Const. Omnem $\S$ 1: 'solis a professoribus traditis Pauliana responsa per semet ipsos recitabant'.

46 Const. Omnem $\S 5$ : 'solitum est anni quarti studiosos Graeco et consueto quodam vocabulo $\lambda$ ن́ $\alpha$ s appellari'.

47 Const. Omnem $\S 1$ : 'et is erat in quartum annum omnis antiquae prudentiae finis'.

48 Const. Omnem $\S$ 1: 'per inperfectum et iam quodammodo male consuetum inconsequentiae cursum'.

49 Const. Omnem $\S 5$. 
TABLE 1 The old curriculum.

\begin{tabular}{|c|c|c|c|c|}
\hline 1st year & 2nd year & 3rd year & 4th year & $5^{\text {th }}$ year \\
\hline (Dupondii) & (Edictales) & (Papinianistae) & (Lutai) & (Prolutai) \\
\hline Gaius & Ta próta & (continuous) & Responsa & Constitutiones \\
\hline \multirow[t]{3}{*}{$(2-3)$} & & De Iudiciis & Pauli & \\
\hline & & and & & (from) \\
\hline & & De Rebus & & \\
\hline and & and & and & & C. Theodosianus \\
\hline De re uxoria & De Iudiciis & & & \\
\hline De tutelis & & Responsa & (self-tuition) & C. Gregorianus \\
\hline De testamentis & and & Papiniani & & \\
\hline De legatis & De Rebus & (libri octo) & & C. Hermogenianus \\
\hline
\end{tabular}

new curriculum and was replaced by the vir subtilissimus Papinian ${ }^{50}$. Leaving out Paulus's Responsa as one of the main-stays of the new curriculum, there remained three constituent components: one concentrating on the libri ad Sabinum, one on the libri ad edictum and one on the person of Papinian and his Responsa. This is the origin of Bluhme's famous 'Massen'. We can now turn to the introduction of the new curriculum and the role it played in the composition of the Digest.

In Deo auctore Justinian left the extraordinary Tribonian ${ }^{51}$ a free hand in selecting the members of the drafting-committee. It consisted of sixteen members $^{52}$, presided over by Tribonian himself ${ }^{53}$, assisted by a high-ranking civil

50 There is one name prominently absent in Justinian's description of the old curriculum and that is Ulpian. He is mentioned neither here, nor in Const. Tanta, which is remarkable, since he is the main contributor to the Digest and was the mainstay of the entire old curriculum We will return to this phenomenon later.

$5^{1} \quad$ His special position is emphasized by the fact that the whole project was his responsibility, since Justinian addressed the Const. Deo auctore, the imperial decree of 530 announcing the project of the Digest, to Tribonian personally.

$5^{2} \quad$ Const. Tanta $\S 9$.

53 Const. Tanta § 9: 'gubernatione Triboniani viri excelsi'. On the role of Tribonian: T. Honoré, Tribonian, London 1978. 
servant, Constantinus, who had also been a member of the committee drafting the first Codex Justinianus of $529^{54}$. Four of them were law professors from Constantinopel (Theophilus and Cratinus) and Beirut (Dorotheus and Anatolius). The other members ${ }^{55}$ were practising lawyers from the bar. The four professors from Beirut and Constantinople formed the academic staff at the heart of the committee, since they shared common experiences which parts of the writings of the classical jurists were obsolete and which were not. However, there was a legal nicety to be settled before a definitive selection could be made, since at the time of the composition of the Digest, the first Codex Justinianus (529) was still in force and it contained, as we know for certain by sheer luck, the Lex citandi ${ }^{56}$. Justinian's drafting committee was, in fact, in the process of making that provision redundant by replacing it with another imperial constitution, the Digest. The question now was, whether the committee was bound by the provision of the Lex citandi, which attributed a special position to the opinion of Papinian in case there was a conflict of opinions among the other authoritative jurists, mentioned in the Lex citandi ${ }^{57}$. Justinian decided to exempt his committee from this provision, thereby downgrading the special position of Papinian ${ }^{58}$, who was to be compensated by a special position in the composition of the quarta pars of the Digest ${ }^{59}$. Having settled this, he addressed an instruction to Tribonian, summarized in Const. Deo auctore $\S 5$ :

Cumque haec materia summa numinis liberalitate collecta fuerit, oportet eam pulcherrimo opere extruere et quasi proprium et sanctissimum templum iustitiae consecrare et in libros quinquaginta et certos titulos

54 Constantinus was magister scrinii (Const. Tanta § 9) and provided the clerical staff executing the operation.

55 Stephanus, Menas, Prosdocius, Eutolmius, Timotheus, Leonides, Leontius, Platon, Iacobus, Constantinus and Johannes.

$5^{6}$ I refer, of course, to the famous Oxyrhynchus papyrus no 1814 (The Oxyrhynchus Papyri, XV, ed. Bernard P. Grenfell and Arthur S. Hunt, London 1922, no. 1814 (220)).

C.Th. 1,4,3: (post alia) 'Ubi autem diversae sententiae proferuntur, potior numerus vincat auctorum, vel, si numerus aequalis sit, eius partis praecedat auctoritas, in qua excellentis ingenii vir Papinianus emineat, qui ut singulos vincit, ita cedit duobus'.

$5^{8}$ Const. Tanta $\S 20 a$ : 'Legis latores autem vel commentatores eos elegimus, qui digni tanto opere fuerant et quos et anteriores piissimi principes admittere non sunt indignati, omnibus uno dignitatis apice impertito nec sibi quodam aliquam praerogativam vindicante'. Comp. Const. Deo auctore $\S 5$ i.f.: 'omnibus auctoribus iuris aequa dignitate pollentibus et nemini quadam praerogatiua servanda'.

59 On this bellissima machinatio see infra, n. 73 . 
totum ius digerere, tam secundum nostri constitutionum codicis quam edicti perpetui imitationem.

Accordingly, before the actual work on the Digest started, two guiding principles were established: the Digest was to be composed following the arrangement of the Codex Justinianus and the Edictum perpetuum (read: Ulpian's libri ad edictum $)^{60}$ and it was to be divided into exactly fifty books, each to be subdivided into a certain number of titles. In the course of the project a third guiding principle evolved, as was stated three years later, in Const. Tanta $§ 1$ i.f.:

Et in septem partes eos <libros $>$ digessimus, non perperam neque sine ratione, sed in numerorum naturam et artem respicientes et consentaneam eis divisionem partium conficientes.

The distribution into partes originated in the old legal curriculum, as is clarified by the names assigned to three of the partes of the Digest: Ta Próta (D. Book 1-4), De iudiciis (D. Book 5-11) and De rebus (D. Book 12-19). The decision to compress the entire Roman jurisprudential tradition into a comprehensive 'restatement' divided into seven partes implied a reconstruction of the traditional legal curriculum and also a rearrangement of the original partes as can

60 Justinian's reference to the Edictum perpetuum as a model for the arrangement of the Digest cannot have been a reference to the actual Edictum perpetuum as it is supposed to have been composed by the lawyer Julian (edicti perpetui subtilissimus conditor) on the instruction of Hadrian (Const. Tanta, $\S 18$ ). But for Justinian's reference to this 'small

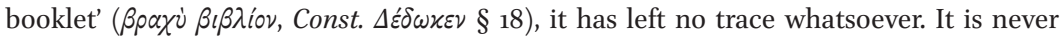
mentioned by any of the Roman lawyers, whereas Julian is only referred to in Const. Tanta as 'edicti perpetui subtilissimus conditor' because he was the author (conditor) of a book on

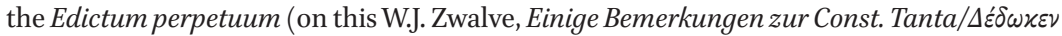
par.18, Tijdschrift voor Rechtsgeschiedenis, $5^{1}$ (1983), p. 139-145). In fact, the only source from which the provisions of the Edictum perpetuum could have been collected in Justinian's time were the libri ad edictum as composed by Gaius, Pomponius, Paul and, of course, Ulpian. The libri ad edictum of the latter were the authoritative restatement of the ius honorarium in post-classical times and were used accordingly in the law schools. Consequently, when Justinian speaks of the arrangement of the Edictum perpetuum, what is actually meant by that is the arrangement of Ulpian's libri ad edictum. There are no direct quotations from the Edictum perpetuum in the Digest. It is always quoted ('praetor ait', or 'ait praetor', etc.) indirectly and (almost) exclusively from Ulpian's libri ad edictum. I counted 183 quotes from the Edictum perpetuum in the Digest ('praetor ait', or 'ait praetor', etc.). Only 4 of them (in D. 2,7,4; 4,7,8; 9,4,31 and 43,3,2) are from Paulus's libri ad edictum; the rest is always from Ulpian's libri ad edictum. None of them quotes from Julian's legendary 'restatement' of the Edictum perpetuum. 
be shown by the reform of the legal curriculum in the first year and the final rearrangement of Ta Próta in D. Book 1-4.

Originally, i.e. in the old curriculum, $\tau \dot{\alpha} \pi \rho \hat{\omega} \tau \alpha$ consisted of the first fourteen books of Ulpian's commentary ad edictum and was read in the first weeks or months of the second year in the (old) curriculum. The committee decided to change this, since the old arrangement was, as Justinian says, 'preposterous' ${ }^{61}$. On the principle of 'first things first', $\tau \dot{\alpha} \pi \rho \hat{\omega} \tau \alpha$ ought to move to the first year of the new curriculum, to be read there after the introductory reading of Gaius's Institutiones. I think that it was at this point (early on, that is, in the compilation-process), that the committee realised that it was inevitable to replace Gaius's Institutiones in the curriculum. There is no mention of this in Const. Deo auctore (530), but there is (three years later) in Const. Tanta (§ 11):

Sed cum prospeximus, quod ad portandam tantae sapientiae molem non sunt idonei homines rudes et qui in primis legum vestibulis stantes intrare ad arcana eorum properant, et aliam mediocrem eruditionem praeparandam esse censuimus, ut sub ea colorati et quasi primitiis omnium imbuti possint ad penetralia eorum intrare et formam legum pulcherrimam non coniventibus oculis accipere. Et ideo Triboniano viro excelso, qui ad totius operis gubernationem relectus est, nec non Theophilo et Dorotheo viris illustribus et facundissimis antecessoribus accersitis mandavimus, quatenus libris, quos veteres composuerunt, qui prima legum argumenta continebant et institutiones vocabantur, separatim collectis, quidquid ex his utile et aptissimum et undique sit elimatum et rebus, quae in praesenti aevo in usu vertuntur, consentaneum invenitur, hoc et capere studeant et quattuor libris reponere et totius eruditionis prima fundamenta atque elementa ponere, quibus iuvenes suffulti possint graviora et perfectiora legum scita sustentare.

It is to Justinian's credit that he does with the Institutes what he fails to do with the Digest, i.e. naming the primary source on the basis of which the text was composed (Ulpian) ${ }^{62}$. Whereas he does not mention him explicitly in the

61 Const. Omnem $\S 1$ : 'in secundo autem anno praepostera ordinatione habita prima pars legum eis tradebatur'.

62 The suggestion that Ulpian's books ad edictum and ad Sabinum were the basis from which Justinian's drafting committee worked was, of course, one of the main contentions of Franz Hofmann (Die Compilation der Digesten (supra, n. 6), p. 46-58). I concur with that view. Even T. Honoré must admit that '(i)f anything really counted as a 'predigest' it would be Ulpian's oeuvre' (Justinian's Digest (supra, n. 3), p. 103). 
passage from Tanta cited above - even boasting, as he does with the Digest, that the Institutes were carefully composed from almost all the elementary textbooks the ancient jurists had composed ${ }^{63}$-, he does mention Gaius by name in the Const. Imperatoriam as the primary source of the Institutes ${ }^{64}$. Since we purport to study the composition of the Digest and its partes, rather than the Institutes, we will leave the latter alone and concentrate on the prima pars legum that was to be the follow-up of the Institutes in the first year of the new curriculum ${ }^{65}$.

Three consequences followed from the decision to fit the prima pars of Ulpian's commentary ad edictum into the new first year elementary course. Firstly, its elementary character should be emphasized by composing it out of four books according to 'the doctrine of numbers' (ex numerorum natura et arte), as Justinian also did with the Institutes ${ }^{66}$. Secondly, the first book of the (new) prima pars should also contain some distinct elementary titles unrelated to the libri ad edictum, and therefore not to be found in the prima pars of Ulpian's commentary ad edictum, such as some of the basics of jurisprudence (Book 1, tit. 1, De iustitia et iure); legal history (Book 1, tit. 2, De origine iuris); sources of law (Book 1, tit. 3-4); and some basic concepts of the law of personal status (Book 1, tit. 5-7). In accordance with the sequence of similar titles in the first book of Justinian's Codex (one of the guiding principles), the rest of the first book was composed of titles concerning various Roman officials (Book 1, tit. 9-22). It is only from the second book of the prima pars of the Digest that the subject matter covered by Ulpian's $\Pi \rho \omega \tau \tau \alpha$ begins (Book 2, tit. 1, De iurisdictione) and continues till the end of that pars, to be carried on into the next pars (Book 5, tit. 1, De iudiciis - Book 11,8, De mortuo inferendo). The third consequence was that there was no room left in the first year of the new curriculum for a reading of the subjects covered by the four libri singulares from Ulpian's ad Sabinum. Since the readings from these four monographs were considered indispensable, room had to be found for them elsewhere in the curriculum. It was available in the course of the second year.

As was shown above, the law professors of the old curriculum read the three initial partes of Ulpian's commentary ad edictum successively, spread out over the second and third year: Ta próta, De iudiciis and De rebus. After the

\footnotetext{
63 Const. Omnem § 2: 'institutiones ex omni paene veterum institutionum corpore elimatas'.

64 Const. Imperatoriam $\S 6$ : 'ex omnibus antiquorum institutionibus et praecipue ex commentariis Gai nostri'.

65 Const. Omnem $\S 2$ : 'in reliquam vero anni partem secundum optimam consequentiam primam legum partem eis tradi sancimus, quae Graeco vocabulo $\pi \rho \omega \hat{\tau} \tau \alpha$ nuncupatur'.

66 Const. Imperatoriam $\S$ 4: 'in hos quattuor libros easdem institutiones partiri iussimus, ut sint totius legitimae scientiae prima elementa'.
} 
completion of this programme during the course of the third year, there was some time left which was devoted to readings from Papinian's Responsa. The transfer of readings from Ta próta to the first year in the new curriculum allowed for a more rational restructuring of the curriculum in the second and third year. Only two partes of the readings ad edictum - De iudiciis and De rebus - were left for the second and third year, amounting to what is substantively a course in property law (De iudiciis) and the law of obligations (De rebus (credi$t i s)$ ). The compilers (surely the law professors among them) decided to discontinue the practice of consecutive reading of these two partes. It seemed obvious to make a clear distinction and to have readings on property law (De iudiciis) and the law of obligations (De rebus creditis) in the second and third year of the curriculum alternatively, leaving room for extra readings of other sources in the second and third year each. Justinian approved of this decision ${ }^{67}$ and consequently the readings of the subjects formerly covered by the four libri singulares from Ulpian's commentary ad Sabinum were transferred from the first year to the second year, to be read after the edictal part (De iudiciis or De rebus) of the courses in that year were finished ${ }^{68}$. The original four libri singulares De re uxoria and De tutelis and De testamentis and De legatis - were replaced by their for educational purposes most suitable counterparts in the Digest: Book 23 (De sponsalibus) and Book 26 (De Tutelis) from the Quarta pars Digestorum and Book 28 (De testamentis liber primus) and Book 30 (De legatis et fideicommissis liber primus) from the Quinta pars Digestorum. Each of these four books from the Digest was the first book of four more extensive volumes (compositiones) incorporated in the fourth and fifth pars of the Digest ${ }^{69}$ : Book 23 is the first book of the tripartite volume (tripertitum volumen) De dotibus (D. 23-25); Book 26 is the first of the bipartite volume (gemini libri) De tutelis et curationibus (D. 26-27); Book 28 is the first of De testamentis libri duo (D. 28-29) and Book 30 is the first of the libri quinque de legatis et fideicommissis (Book 30-34) ${ }^{70}$. Justinian describes the whole operation as follows:

67 Const. Omnem $\S 3$ : 'In secundo autem anno, per quem ex edicto eis nomen antea positum et a nobis probatur, vel de iudiciis libros septem vel de rebus octo accipere eos sancimus, secundum quod temporis vicissitudo indulserit, quam intactam observari praecipimus'.

68 Const. Omnem $\S 3$ : 'alterutri autem eorundem volumini, id est de iudiciis vel de rebus, adiungi in secundi anni audientiam volumus quattuor libros singulares'.

69 Const. Omnem $\S 3$ : 'quattuor libros, qui in primordiis singularum memoratarum compositionum positi sunt'.

$70 \quad$ See also Const. Tanta $\S$ 6: 'De legatis autem et fideicommissis quinque librorum numerus adgregatus est'. In Omnem $\S 3$ Justinian counts seven books De legatis et fideicommissis, probably because he adds the two final books in the pars quinta on the lex Falcidia and the sc Trebellianum (D. 35 en 36 ). 
quattuor libros singulares, quos ex omni compositione quattuordecim librorum excerpsimus: ex collectione quidem tripertiti voluminis, quod pro dotibus composuimus, uno libro excerpto. ex duobus autem de tutelis et curationibus uno: et ex gemino volumine de testamentis uno: et ex septem libris de legatis et fideicommissis et quae circa ea sunt simili modo uno tantum libro. hos igitur quattuor libros, qui in primordiis singularum memoratarum compositionum positi sunt, tantummodo a vobis eis tradi sancimus, ceteris decem oportuno tempori conservandis : quia neque possibile est neque anni secundi tempus sufficit ad istorum quattuordecim librorum magistra voce eis tradendorum recitationem ${ }^{71}$.

After having thus secured the continuity of traditional legal education, there remained the room left in the third year for additional readings after the readings from the mandatory edictal part (De iudiciis or De rebus) in that year were finished. Traditionally, the extra time available in the third year of the old curriculum was devoted to readings from Papinian's Responsa. It was the reason why, under the old curriculum, third-year students were designated as Papinianistae, since it was in their third year that they were introduced to his writings ${ }^{72}$. As a matter of course, this tradition had to be preserved in the new curriculum as well. In order to ensure that third-year students retained their ancient title of 'Papianistae' Justinian (or rather Tribonian) concocted his famous 'bellissima machinatio', highlighting Papinian's position in the new curriculum for the third year ${ }^{73}$. Instead of readings from Papinian's Responsa only, the professors were instructed to read three libri singulares from the Umbilicus, the middle part of the Digest (Books 20-27), to wit Book 20 (liber singularis ad formulam hypothecariam), Book 21 and Book $22^{74}$, all very symbolical, since the students were now, in their third year, also 'at the navel' of the programme. In

$71 \quad$ Const. Omnem $\S 3$.

72 Const. Omnem $\S$ 1: 'ad sublimissimum Papinianum eiusque responsa iter eis aperiebatur'.

73 Const. Omnem $\S$ 4: 'ne autem tertii anni auditores, quos Papinianistas vocant, nomen et festivitatem eius amittere videantur, ipse iterum in tertium annum per bellissimam machinationem introductus est'.

74 In Const. Omnem $\S 4$ Justinian speaks of an additional 'tripertita legum singularium dispositio' and mentions only two explicitly, the liber singularis ad formulam hypothecariam (Book 20) and the liber singularis de aedilicio edicto et de redhibitoria actione et de evictionibus nec non duplae stipulatione (Book 21). Since we know that, in their second year, students read, in addition to either the 'pars De rebus', or the 'pars De iudiciis', also book 23 of the 'Umbilicus' (being the first part of the tripartite book De dotibus (Books 23-25 (Const. Omnem, § 3)), it follows that Book 22 (De usuris et traiecticiis pecuniis) must have been the third book to complete Justinian's additional 'tripartita legum singularium dis- 
honour of Papinian, Justinian instructed his drafting committee to change the usual distribution of fragments from the writings of the jurists over the titles of each book in the case of the six titles of Book 20 (ad formulam hypothecariam) by putting a fragment from Papinian at the beginning of each of the titles of which it was composed ${ }^{75}$. The compilators followed this instruction but for Title 3, where they put a fragment from Marcianus's liber singularis ad formulam hypothecariam at the forefront, thereby honouring that Roman expert in the law of security interests. Papinian's special position was even further emphasized by the fact that the entire Quarta pars Digestorum, 'totius compositionis quasi umbilicus ${ }^{76}$, initiated with a fragment from the Responsa of that famous lawyer (D. 20,1,1, Papinianus, libro undecimo Responsorum), another hint at the ancient academic tradition.

As Justinian explicitly emphasizes, the Quarta and Quinta pars of the Digest were reserved to contain all the 'monographs' that were to be taught at the law schools in addition to the 'core part' of legal education, i.e. Ulpian's libri ad edictum, as extended in Books 1-19 of the Digest and spread out over the first three partes ${ }^{77}$. The professors had to read D. 23 and 26 (De sponsalibus and De Tutelis from the Quarta pars) and D. 28 and 30 (De testamentis and De Legatis (1) from the Quinta pars) in the second year. The third year was completed by 'Papinian' readings (Book 20-22 from the Quarta pars exclusively, essentially a course on credit and security interests), as explained above.

We can now proceed to the fourth year of the new curriculum and the subjects to be studied in that year, traditionally reserved for the private study of Paulus's Responsa. In the new Justinian scheme, this year was also reserved for self-tuition, but not on the basis of Paulus's Responsa, but in order to complete the gaps left in the 'Sabinian' (ius civile) part of the curriculum. Students had

positio' of the third year. This was the conclusion of Scheltema (Enseignement (supra, n. 7), p. 8); see also Heimbach, Prolegomena (supra, n. 6), p. 2 ('haud dubie').

Const. Omnem, § 4: 'librum enim hypothecariae ex primordiis plenum eiusdem maximi Papiniani fecimus lectione, ut et nomen ex eo habeant et Papinianistae vocentur.'

$76 \quad$ Const. Tanta $\S 5$.

77 Const. Omnem $\S 5$ : 'omnis ordo librorum singularium a nobis compositus et in decem et septem libros partitus ... quem in duabus digestorum partibus posuimus, id est quarta et quinta, secundum septem partium distributionem'. The list is as follows: libri singulares Ad formulam hypothecariam (D. 20); De aedilicio edicto (D. 21); De Usuris et traiecticiis pecuniis et de instrumentis (D. 22); De sponsalibus (D. 23); De nuptiis (D. 24); De dotibus (D. 25) and De tutelis et curationibus libri duo in the Quarta pars. The Quinta pars was composed of De testamentis libri duo (D. 28-29); De legatis et fideicommissis libri quinque (D. 30-34) and two libri singulares, one De lege Falcidia and another Ad sc Trebellianum (D. 35-36). 
heard introductory classes in their second year on De sponsalibus and De tutelis (from the Quarta pars) and on De testamentis and De legatis (from the Quinta pars), but only the first books of these four compositiones. Now, in their fourth year, they had to read all of it without the learned assistance of their professors. Justinian circumspectly prescribes which of the left over books from these partes had to be read in this year. He is careful to point out that the sum of all the volumina, the greater units within each pars, contained in the Umbilicus and the pars De testamentis is seventeen ${ }^{78}$. After having read the three first books (Book 20-22) of Umbilicus in the previous (third) year, there remained fourteen books to be read from what Justinian called the compositio quattuordecim librorum $^{79}$, being the units De dotibus (three books) and De tutelis et curationibus (two books) from Umbilicus and De testamentis (two books) and De legatis et fideicommissis (seven books) from the pars De testamentis. Four books of this compositio had already been read in the second year (Book 23; 26; 28 and 30), which leaves ten books to be studied by the students in their fourth year. In this way, says Justinian, all 17 books of Umbilicus and the pars De testamentis together will have been studied ${ }^{80}$. He could have said it much simpler ('what is left of the Umbilicus and the pars De testamentis), but he prefers to juggle with numbers here, as he does elsewhere, for example when he describes the last book of the Digest as the sixth of the last pars and the fiftieth of the entire composition $^{81}$.

\section{Excursus: Juggling with numbers}

Justinian's (Tribonian's) propensity to juggle with numbers is also expressed in the number of books each of the seven partes of the Digest was to be composed of. My good friend, the mathematician Theo de Vries, has made a study of it, which I am happy to add at this point ${ }^{82}$. Consider table 2 , showing the distribution of books over the seven partes Digestorum.

It is obvious that there is a discrepancy between the number of books attributed to the pars prima and the distribution of books over the remaing six

78 Const. Omnem, $\S 5$ : 'decem et septem libros partitus (...) quem in duabus digestorum partibus posuimus, id est quarta et quinta, secundum septem partium distributionem'.

79 Const. Omnem, § 3 .

$80 \quad$ Const. Omnem, $\S 5$ : 'decem libros singulares, qui ex quattuordecim quos antea enumeravimus supersunt, studeant lectitare (...) et ita omnis ordo librorum singularium a nobis compositus et in decem et septem libros partitus eorum animis inponetur'.

81 Const. $\triangle \varepsilon ́ \delta \omega \varkappa \varepsilon \nu \S 8$ i.f.

82 Theo de Vries's mathematical analysis is added in the Appendix to this article. 
TABLE 2 Distribution of books over the seven partes Digestorum.

\begin{tabular}{|c|c|c|c|c|c|c|c|c|}
\hline & $\begin{array}{l}\text { Pars } \\
\text { prima } \\
(\text { Ta } \\
\text { Próta) }\end{array}$ & $\begin{array}{l}\text { Pars } \\
\text { secunda } \\
\text { (De } \\
\text { iudiciis) }\end{array}$ & $\begin{array}{l}\text { Pars } \\
\text { tertia } \\
(D e \\
\text { rebus })\end{array}$ & $\begin{array}{l}\text { Pars } \\
\text { quarta } \\
\text { (Umbilicus) }\end{array}$ & $\begin{array}{l}\text { Pars } \\
\text { quinta } \\
\text { (De testa- } \\
\text { mentis) }\end{array}$ & $\begin{array}{l}\text { Pars } \\
\text { sexta } \\
\text { (De bonn. } \\
\text { poss.) }\end{array}$ & $\begin{array}{l}\text { Pars } \\
\text { septima } \\
\text { (s.n.) }\end{array}$ & Total \\
\hline Books & $\begin{array}{l}4 \\
(1-4)\end{array}$ & $\begin{array}{l}7 \\
\left(5^{-11}\right)\end{array}$ & $\begin{array}{l}8 \\
(12-19)\end{array}$ & $\begin{array}{l}8 \\
(20-27)\end{array}$ & $\begin{array}{l}9 \\
(28-36)\end{array}$ & $\begin{array}{l}8 \\
(37-44)\end{array}$ & $\begin{array}{l}6 \\
\left(45^{-5} 5^{0}\right)\end{array}$ & $5^{0}$ \\
\hline
\end{tabular}

partes. The number of four books attributed to the pars prima was of course inspired by the elementary nature of that pars $(\tau \dot{\alpha} \pi \rho \omega \hat{\tau} \tau)$ and the 'doctrine of the nature of numbers' referred to in Const. Tant $\S 1$. It was, therefore, a predetermined number, but it confronted the mastermind behind the project (Tribonian) with a considerable mathematical problem: how to distribute the remaining 46 books over the residual six partes?

The Digest was, by order of Justinian himself, preconceived as a templum iustitiae $^{83}$ and should therefore also be composed in a harmonious way, based on the idea of symmetry, just as Justinian's other great monument to posterity, the Hagia Sophia. That this was indeed the case can be illustrated by the Quarta pars, the middle part of the Digest, 'the navel' (umbilicus) ${ }^{84}$, which contains $5^{0}$ titles $^{85}$, in harmonious conformity, that is, with the total number of books the Digest was to be composed of ${ }^{86}$. The number fifty was very dear to Justinian. H.J. Scheltema, who was first in trying to explain the meaning of this number $^{87}$, has made a strong case for the possibility that the Digest was originally

83 Const. Deo auctore $\S 5$.

84 Const. Tanta $\S 5$.

85 As far as I have been able to assess, H.J. Scheltema was the first to draw attention to this curious phenomenon, Over getallen in het Corpus Iuris Civilis, in: E. Alkema (ed.), Vrijheid en recht, Opstellen aangeboden aan prof. mr E.H. s'Jacob, Zwolle 1975, p. 227-234 (232) and (idem), Subseciva XVIII: Les quinquaginta decisiones, Subseciva Groningana, 1 (1984),p. 1-9 (Opera Minora, p. 395-402 and 158-162).

86 Const. Deo auctore $\S 5$.

87 Not the first, though, to note the frequent occurrence of the number fifty. See already $\mathrm{H}$. Bluhme, Die Ordnung der Fragmente (supra, n. 2), p. 356 (n. 7): 'Fast möchte man glauben, die Zahl 50 habe zu seinen Lieblingszahlen gehört, da er auch so gerne seiner 50 decisiones erwähnt'. I venture to add, in a footnote, my own guess about the meaning of the number $5^{0 .}$ Numerology was taken very seriously in sixth-century Constantinople. It was 'immensely popular' (M. Maas, John Lydus and the Roman Past, London 1992, p. 59). It was 


\begin{tabular}{|c|c|c|c|c|c|c|c|c|}
\hline & $\begin{array}{l}\text { Pars } \\
\text { prima } \\
(\text { Ta } \\
\text { Próta })\end{array}$ & $\begin{array}{l}\text { Pars } \\
\text { secunda } \\
\text { (De } \\
\text { iudiciis) }\end{array}$ & $\begin{array}{l}\text { Pars } \\
\text { tertia } \\
(\text { De } \\
\text { rebus })\end{array}$ & $\begin{array}{l}\text { Pars } \\
\text { quarta } \\
\text { (Umbili- } \\
\text { cus) }\end{array}$ & $\begin{array}{l}\text { Pars } \\
\text { quinta } \\
\text { (De } \\
\text { testamentis) }\end{array}$ & $\begin{array}{l}\text { Pars s } \\
\text { exta } \\
\text { (De bonn. } \\
\text { poss. })\end{array}$ & $\begin{array}{l}\text { Pars } \\
\text { septima } \\
(\text { s.n.) }\end{array}$ & Total \\
\hline Books & 4 & 7 & 8 & 8 & 8 & 8 & 7 & $5^{0}$ \\
\hline
\end{tabular}

planned to be presented to the emperor at the occasion of his fiftieth birthday, an event unfortunately frustrated by the Nikè-revolt. Be this as it may, the total number of 50 books for the Digest as a whole was preordained, as was the number of four books to be attributed to the first pars. So, how to distribute the remaining 46 over the residual 6 partes in a way that is harmonious and symmetrical as well? The obvious solution is in table 3 .

The distribution of books over the remaining six partes as shown here represents a case of 'strong symmetry': the remaining 6 partes are divided into two equal parts, consisting of 23 books each, whereas these two equal parts mirror each other in perfect symmetry, a parabola, forming, as it were, a kind of mathematical "dome" over the templum iustitiae. However, this is not what Tribonian did, due to the constraints implied by the implementation of the academic curriculum in the composition of the Digest. Justinian had not only preordained that the Digest as a whole should number exactly $5^{0}$ books, but also that the compulsory readings of the Digest (public, as well as private) should be concluded at the end of the Quinta pars (Book 36). Justinian's assessment, repeated twice in Const. Omnem, that the first 36 books of the Digest sufficed for the study of the law, since, after having read these 36 books, the students were 'perfecti et ad omne opus legitimum instructi'88, is the only explicit reference to numerological concepts in the Corpus Iuris ${ }^{89}$. This compli-

also taken seriously by Justinian (see infra, $\mathrm{n}$. 88), if only because omnia mensura, numero et pondere disposuisti (Sapientia 11:21). F. Hofmann (Die Compilation der Digesten (supra, n. 6), p. 181-200) was right to draw attention to this. Now the number 50 stands for 'conclusion', or 'completion', since it is the sum of a complete cycle of 7 (the seven partes Digesto$\operatorname{rum}(!))$ plus one $(7 \times 7+1)$, as is shown by the calculation of the Jubilee (the fiftieth year) in Leviticus 25:10-11: 7 x 7 (Lev. 25:8) + 1 (Lev. 25:9).

88 Const. Omnem $\S 5$. The other reference to 36 books completing the study of the Digest is in Const. Omnem, pr.

89 The number 36 was highly meaningful in Pythagorean numerology, since it signified perfection, as did the famous 'tetractus' $(1+2+3+4=10)$. The sum of the even numbers under 10 
cated the problem of an even distribution of all the 46 books over all the remaining six partes even more, since Tribonian had to conceive of a distribution of books concluding with book 36 at the end of the Quinta pars. This could not be achieved in the ideal 'strongly symmetrical' model as presented above, since the Quinta pars would have ended at the 'imperfect' number of 35, rather than the 'perfect' number ${ }^{90}$ of 36 . Consequently, the Quinta pars was predestined to contain more books than the Quarta pars. The Quarta and Quinta pars Digestorum together were reserved to contain all the libri singulares (in the sense of 'monographs') that were to be taught at the law schools in addition to the 'core part' of legal education (Ulpian's libri ad edictum, as extended in Books 1-19 and spread over the first three partes of the Digest) and should, therefore, have a total number of seventeen (not sixteen) books together, as Justinian explicitly emphasizes ${ }^{91}$. There is no way to divide 17 books in two equal parts of whole numbers and so the Quinta pars was to be artificially extended, which explains the curious phenomenon of no less than three homonymous books De legatis et fideicommissis (Book 30-32) in that pars. Since, for reasons of balance and symmetry, the distribution of books over all the remaining six partes had to come as close as possible to the mean $(7$ or 8$)$ for each pars, the amount of nine books for the Quinta pars was imperative. It left Tribonian with only one possibility to achieve a model of 'weak symmetry' by holding on to a division of the six partes in two equal parts, consisting of 23 books each, and by assigning 8 books to the Sexta pars and 6 to the final and seventh pars of the Digest, rather than 7 to each of the last two partes, since doing so would have flattened the 'dome' out of proportion that he was clearly trying to erect in his numerical exercise with the partes Digestorum. The allotment of eight books to the Sexta pars and the remaining six to the Septima must have been predetermined by this mathematical exercise, since Justinian explicitly states in Const. Tanta that the subjects contained in Book 44 (the last Book of the Sexta pars) were purposely added 'in order that the sixth pars is

$(2+4+6+8)$ and the uneven numbers under $10(1+3+5+7)$ equals 36 . Plutarchus deals extensively with this number (36) in his De animae procreatione in Timaeo: Plutarchus, Moralia XIII, part 1 (transl. H. Chernis, Loeb Classical Liberary), 1018 C-D (278-282). See on this number (36) also Plutarchus, De Iside et Osiride, Moralia V (transl. F. Cole Babbit, Loeb Classical Library), p. $382(178)$, where it is said that that number $(36)$ is called 'World' (xó $\mu \circ$ s).

9o The adjective 'perfect' is used here in a metaphorical way, so the expression "perfect' number' used in the text is not to be understood as referring to the mathematical (Euclidean) concept of 'perfect', or 'complete' numbers.

See supra, n. 78 . 
composed of eight books'92, showing that there was a systematic constraint preventing the Digest as a whole to be concluded with a last and seventh pars consisting of seven books as well, 'secundum septem partium distributionem'.

Exercises like this - how to divide a given number (46) in 6 whole numbers creating a domelike structure - were inspired by the mathematics of Diophantus of Alexandria ( $f$ l. $250 \mathrm{AD}$ ). It was Constantinople, rather than Rome, that saved the Greek mathematical tradition from oblivion; Anthemius of Tralles, for example, one of the architects of Hagia Sophia, was an accomplished mathematician. Tribonian himself may very well have been familiar with this kind of equations, certainly so if he is to be identified with the learned Tribonian of

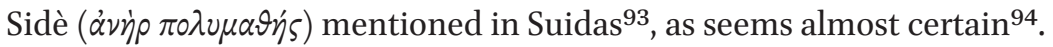

$92 \quad$ Const. Tanta $\S 7$ e: 'ut praefata sexta pars ... octo libris definiatur'.

93 Suidae Lexicon, t. 957 (Tpıßouvıavós), ed. A. Adler,Vol. I, pars 4, Leipzig 1935, 588.

94 H.J. Scheltema, Over getallen in het Corpus Iuris Civilis (supra, n. 85), p. 227-228 (Opera Minora 395-396). Suidas mentions no less than four Triboniani: one (Tpıßovvıavós) who

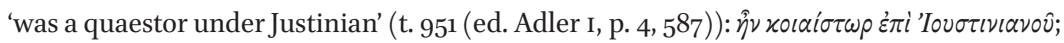
another (t. 956, Tpıßouviavós (ed. Adler I, p. 4, 588)) who is said to have been a barrister in

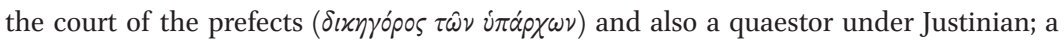
third Tribonian from Sidè (t. 957: Tpıßovvıavós $\Sigma ı \delta \dot{\eta} \tau \eta$ ), who is also said to have been among the barristers in the court of the prefect and who was a polymath too, having written books, among others, 'On the universal and harmonic arrangement'; 'the ruling and governing planets'; 'the houses of the planets' and 'the 24 metrical feet and the 28 rhythmical ones'. The fourth Tribonian mentioned in Suda appears in a lemma on the historian Agathias (a 112 (ed. A. Adler, Vol. I, p. 1, Leipzig 1928, 15)), who is said to have been 'a contemporary of Paulus Silentiarius, and of the consul Macedonius and of Tribonian (Tpıßouviavós) in the time of Justinian'. The last Tribonian is certainly not our Tribonian, since he was a contemporary of Agathias and Paulus Silentiarius and consequently some forty years younger than our Tribonian. Among the books written by the third Tribonian (from Sidè) mentioned in Suidas (t. 957) are also a 'Catalogue of consuls listed up to the

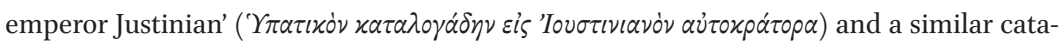

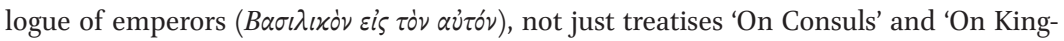
ship' as Honoré (Tribonian (supra, n. 53), p. 67) thinks. Since both of these lists were indispensable for the composition of the Codex Justinianus, Scheltema was convinced they were written by the person responsible for the second edition (repetita praelectio) of that part of Justinian's legislation (Tribonian) and accordingly assumed that our Tribonian wrote the other books mentioned there as well. The second and third Tribonian (t. 956 and 957) may still refer to two different persons (I cannot accept a self-confessed

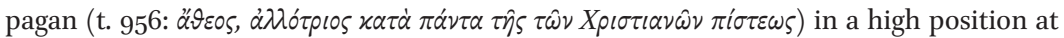
the court of a bigot like Justinian), but much of the information on our Tribonian is spread over three lemmata in Suidas (t. 951, 956 and 957). For a different view see Honoré, Tribonian (supra, n. 53), p. 64-69. 
The Quarta and Quinta pars Digestorum were conceived of as one continuous compositio, consisting of 17 libri singulares students should have studied in order to become perfecti, having read 36 books of the Digest ${ }^{95}$. The Quinta pars concluded the sections of the Digest that were composed on the basis of a scheme dictated by the legal curriculum. Consequently, there is a clear break in the composition of the Digest at the end of Book 36 . It is plainly visible in table 4, when one considers the distribution of titles over the books contained in these partes $^{96}$. The distribution of titles over the first five partes is fairly balanced (between 40 and 52 ), whereas the number of titles in the sixth and seventh pars explodes: no less than 111 (112) in the sixth pars and 93 in the seventh.

The Sexta pars of the Digest still contains one 'monograph', De bonorum possessionibus libri duo (Books 37-38), which is accounted for in the Index titulorum, but after Book 38 all following books of the Sexta and Septima pars are merely numbered ex ordine Digestorum, without any further sign of a predetermined structure behind the composition of these partes other than that the order of the Codex and the Edictum perpetuum respectively is followed. There

95 Const.Omnem $\S 5$ : 'omnis ordo librorum singularium a nobis compositus et in decem et septem libros partitus eorum animis inponetur quem in duabus digestorum partibus posuimus, id est quarta et quinta, secundum septem partium distributionem'. The deliberate cohesion between the Quarta and Quinta pars is also reflected in the Index titulorum. Book 20 of the Digest, the first book of the Quarta pars, is designated as Singularium primus and Book 28 of the Digest, the first book of the Quinta pars is designated as Singularium liber nonus.

96 Caution is required with the number of titles each book of the Digest (except D. 30-32), and the total number of titles the Digest as a whole was composed of, since there are some errors in the Index Titulorum of the Codex Florentinus. In Book 37, Title 15 (De obsequiis parentibus et patronis praestandis) is left out in the Index, and inserted into Book 38 (after D. 38,14 ) of the Index, while it is retained as D. 37,15 in the Digest itself; in Book 41, the Index has a title at the end (D. 41,11, Communia de accessionibus possessionum), which is missing in the Digest itself; in Book 48 is a mistake consisting of an erroneous conjunction of the rubrics of Title 20 and 21; in Book 49, Title 3 is left out, whereas the sequence of Titles 7-10 in the Index is different from the one in the corresponding Book (49) in the Digest itself. A. Soubie, Recherches sur les origines des rubriques du Digeste (supra, n. 37), counts 440 titles in total. Since this problem is not directly related to the subject of this article, it will be left aside. It should be stressed, however, that it is, by any count, undisputed that the Quarta pars consisted of 50 titles in total. I am convinced, by the way, that the total amount of titles in the Digest must have added up to the number of 432, since in Greek gemmatria that number stands for $\pi \alpha^{\prime} \nu \tau \alpha\left(80\left(\pi^{\prime}\right)+1\left(\alpha^{\prime}\right)+50\left(\nu^{\prime}\right)+300\left(\tau^{\prime}\right) 1\left(\alpha^{\prime}\right)\right)$. This is a 'coincidence' that cannot be ignored. 
TABLE 4 Distribution of titles over the books contained in the seven partes.

\begin{tabular}{|c|c|c|c|c|c|c|c|c|}
\hline & $\begin{array}{l}\text { Pars } \\
\text { prima } \\
(\text { Ta } \\
\text { Próta })\end{array}$ & $\begin{array}{l}\text { Pars } \\
\text { secunda } \\
\text { (De } \\
\text { iudiciis) }\end{array}$ & $\begin{array}{l}\text { Pars } \\
\text { tertia } \\
(\text { De } \\
\text { rebus) }\end{array}$ & $\begin{array}{l}\text { Pars } \\
\text { quarta } \\
\text { (Umbili- } \\
\text { cus) }\end{array}$ & $\begin{array}{l}\text { Pars } \\
\text { quinta } \\
\text { (De } \\
\text { testamentis) }\end{array}$ & $\begin{array}{l}\text { Pars s } \\
\text { exta } \\
\text { (De bonn. } \\
\text { poss.) }\end{array}$ & $\begin{array}{l}\text { Pars } \\
\text { septima } \\
\text { (s.n.) }\end{array}$ & Total \\
\hline Books & $\begin{array}{l}4 \\
(1-4)\end{array}$ & $\begin{array}{l}7 \\
\left(5^{-11}\right)\end{array}$ & $\begin{array}{l}8 \\
(12-19)\end{array}$ & $\begin{array}{l}8 \\
(20-27)\end{array}$ & $\begin{array}{l}9 \\
(28-36)\end{array}$ & $\begin{array}{l}8 \\
(37-44)\end{array}$ & $\begin{array}{l}6 \\
\left(45^{-50}\right)\end{array}$ & $5^{0}$ \\
\hline Titles & $5^{2}$ & 40 & 41 & $5^{0}$ & 44 & $\begin{array}{l}111 \\
(112)\end{array}$ & 93 & $\begin{array}{l}431 \\
(432)\end{array}$ \\
\hline
\end{tabular}

was no more connection with the legal curriculum, so the main guiding principle behind the composition of the preceding five partes, the arrangement of the new legal curriculum, had become irrelevant. What was added to these five partes was an appendix, wherein each title of each book is, of course, still structured in a more or less 'Bluhmean' way ${ }^{97}$. The idea that the last two partes of the Digest may be regarded as a kind of 'Appendix' to the five preceding partes is confirmed by a strange peculiarity that becomes highly significant once it is taken into consideration within this context.

It has been convincingly argued ${ }^{98}$ that in the codex Florentinus the quires it is composed of were distributed among the scribes in a way corresponding with the division into partes and even, in as far as the Quarta and Quinta pars

97 It should be conceded that the basic assumption of Bluhme's 1820 article (the distribution of each title of the Digest into a pars Sabiniana, a pars edictalis and a pars Papiniana) is really quite commonplace, since nearly every subject of substantive Roman law always has three aspects: the ius civile, the ius honorarium and the responsa prudentium. It is the same as in English law, where many subjects of substantive private law have three aspects as well: common law, equity and statutory law. At the suggestion of Mike MacNair in Oxford, I consulted Matthew Bacon's New Abridgement and looked at his handling of the doctrine of assignment of choses in action in particular (Vol. 1, London 1736, p. 157-158), since it is in a subject like this that all the three constituent parts of English law play an important role. And indeed: it starts off with the common law, continues with the different approach of equity and concludes with the statement that 'some things are assignable by Act of Parliament which seem not assignable in their own Nature', thus summarizing all three 'Masssen' of English law on this subject in their natural sequence under one headnote ('Assignment'). There is nothing remarkable in this, since it is the obvious way of dealing with a subject like this and so it was, mutatis mutandis, in Roman law.

98 B. Stolte, The partes of the Digest in the Codex Florentinus, Subseciva Groningana, 1 (1984), p. 69-91 (71-77). 
are concerned, the smaller units, the libri singulares. This assessment strongly suggests that the manuscript we know as the codex Florentinus was composed for educational purposes ${ }^{99}$. It confirms the impression that the division into three partes of Ulpian's libri ad edictum, as it was used in the old curriculum, related to the sections that were read in class during a particular season ${ }^{100}$. The point to be stressed in this context, however, is that the transition from the Sexta to the Septima pars, i.e. from Book 44 to Book 45, is the only instance in the manuscript where a change of pars is not marked by a clear separation in the manuscript, since Book 45, the first book of the Septima pars begins on the verso of a leaf, without a change of hand ${ }^{101}$, clearly indicating that, in as far as the scribes of the codex Florentinus and their commissioners were concerned, the last two partes of the Digest were indeed a mere appendix. The books it

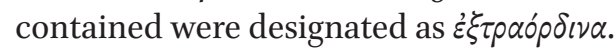

The division of the Digest into partes, made for educational purposes solely and obviously directed by the four professors in the drafting committee (Theophilus and Cratinus from Constantinopel and Dorotheus and Anatolius from Beirut), provided the basic structure for the composition of the Digest, or at least for the first five partes. The object of the professors in the committee, supported by Tribonian, seems to have been to save as much as possible of the old curriculum into the new code of law that they supposed would be the basis of the academic study of the law for future generations. In this they were highly successful. In spite of his repeated boasts of being a radical reformer of legal education, Justinian did not, in fact, change that much altogether. He kept the structure of the old curriculum largely intact. It remained a five-year course, with the fourth year devoted to self-tuition and the fifth and final year committed to the study of imperial legislation exclusively. When seen from this perspective, it is clear that much of the composition of the Digest was already predetermined even before the actual work on it was started, since the structure of the first five partes was preordained by the arrangement of the pre-existing legal curriculum. A look at the new curriculum substantiates this view. It is shown in table 5 .

The structure of the first 19 books of the Digest was preordained by the pre-existing academic practice to read Ta próta, De iudiciis and De rebus (from

\footnotetext{
99 B. Stolte, The partes (supra, n. 98), p. 88.

100 See supra, at n. 40.

101 Stolte, The partes (supra, n. 98), p. 77.
} 
TABLE 5 The new Curriculum.

\begin{tabular}{|c|c|c|c|c|}
\hline 1st year & 2nd year & 3rd year & 4th year & $5^{\text {th }}$ year \\
\hline (Justinianei novi) & (Edictales) & (Papinianistae) & (Lutai) & (Prolutai) \\
\hline Institutes & De Iudiciis & De rebus & $\begin{array}{l}\text { De dotibus } \\
\text { (liber secundus) } \\
\text { (D. 24) }\end{array}$ & $\begin{array}{l}\text { Codex } \\
\text { Justinianus }\end{array}$ \\
\hline \multirow[t]{4}{*}{$(1-4)$} & (D. $5^{-11}$ ) & (D. 12-19) & $\begin{array}{l}\text { De dotibus } \\
\text { (liber tertius) } \\
\text { (D. 25) }\end{array}$ & \\
\hline & OR & OR & $\begin{array}{l}\text { De tutelis } \\
\text { (liber secundus) } \\
\text { (D. 27) }\end{array}$ & \\
\hline & De rebus & De Iudiciis & & \\
\hline & (D. 12-19) & (D. 5-11) & & \\
\hline AND & AND & AND & AND & \\
\hline Ta próta & $\begin{array}{l}\text { De dotibus } \\
\text { (liber primus) } \\
\text { (D. 23) }\end{array}$ & $\begin{array}{l}\text { Ad formulam } \\
\text { hypothecariam } \\
\text { (D. 20) }\end{array}$ & $\begin{array}{l}\text { De testamentis } \\
\text { (liber secundus) } \\
\text { (D. 29) }\end{array}$ & $\begin{array}{l}\text { (all twelve } \\
\text { books) }\end{array}$ \\
\hline \multirow[t]{3}{*}{ (D. 1-4) } & $\begin{array}{l}\text { De tutelis } \\
\text { (liber primus) } \\
\text { (D. 26) }\end{array}$ & $\begin{array}{l}\text { De aedilicio } \\
\text { edicto } \\
\text { (D. } 21 \text { ) }\end{array}$ & $\begin{array}{l}\text { De legatis } \\
(\text { libri II-VII) } \\
\text { (D. } 3^{1-36)}\end{array}$ & \\
\hline & $\begin{array}{l}\text { De testamentis } \\
\text { (liber primus) } \\
\text { (D. } 28 \text { ) }\end{array}$ & $\begin{array}{l}\text { De usuris } \\
\text { (D. 22) }\end{array}$ & (ten books) & \\
\hline & $\begin{array}{l}\text { De legatis } \\
\text { (liber primus) } \\
\text { (D. } 30)\end{array}$ & & (Self-tuition) & \\
\hline
\end{tabular}

Ulpian's commentary ad edictum) consecutively and was spread over the Prima, Secunda and Tertia pars Digestorum in that order. The libri singulares the students had to study in addition to that were conveniently located in a new compositio of seventeen books and spread over the Quarta and Quinta pars (Books 20-36). The structure of the Appendix consisting of the Sexta and Septima pars was merely determined by the order and sequence of the Codex (Books 6,7 and 8 for the Sexta pars and Books 8-12 for the Septima pars) and, where appropriate, the Edictum perpetuum, meaning Ulpian's commentary ad edictum $^{102}$.

102 See supra, n. 6o. The sequence of titles in books 42,43 and 44 of the Sexta pars closely follows Ulpianus ad edictum, books 58-76. 
The legal curriculum that Justinian had so delicately worked into his Digest and that was laid out in detail in his Const. Omnem did not survive his reign for long. The teaching-method secundum partes by the Byzantine antecessores was discontinued not long after his death, sometime between 557 and $572^{103}$. It has never been copied in the West, in spite of the fact that Const. Omnem is included in the Codex Florentinus. The medieval glossators and commentators had no use for it. 'We do things differently', says Accursius ${ }^{104}$.

\section{Appendix}

The Digest consist of 7 partes, each pars consisting of several books. The total number of books contained in the partes is 5 . The actual number of books $x_{i}$ in the individual pars $\mathrm{i}$ is: $x_{i}=4,7,8,8,9,8,6$ for $\mathrm{i}=1, \ldots, 7$. The problem is whether there exists a system which allows us to predict these numbers of books for the consecutive partes.

The first pars is given in advance: it consists of 4 books.

\section{2}

\section{The mathematical formulation}

The problem means that we have to solve , $\mathrm{i}=1, \ldots, 7$, in the following equation:

(1) $\quad \sum_{i=1}^{7}\left(x_{i}\right)=50$

103 Scheltema, Antécesseurs (supra, n. 7), p. 62 (Opera minora p. 102) and N. Van der Wal and J.H.A. Lokin, Historiae iuris graeco-romani delineatio (supra, n. 7), p. 55.

104 Gl. 'Et legere' ad Const. Omnem § 5: 'hodie hic ordo non servatur (...) de facto secus servamus'. On this and some other aspects of Const. Omnem in the medieval Italian law schools see W.J. Zwalve, Text and Commentary, Justinian's Const. Omnem and its medieval commentators, in: K. Enenkel, H. Nellen (edd.), Neo-Latin commentaries and the management of knowledge in the late middle ages and the early modern period (1400-1700), Supplementa Humanistica Lovaniensia nr. 33. Leuven 2013, p. 349-386. I found only one curious remnant of the ancient Justinian division in partes in medieval legal literature. The Commentarii on the three sections in which Justinian's Digest had become to be divided in the Middle Ages (Vetus, Infortiatum and Novum) were traditionally divided into two separate volumes each (e.g. Commentarii in primam et secundam Veteris Digesti partem). The break between the prima pars and the secunda pars of Vetus is always at D. 12,1, which was also the breaking point between the Secunda and Tertia pars of Justinian's division of the Digest in partes. The same phenomenon occurs in the editions of Digestum Novum: the breaking point between the prima and secunda pars of Novum is always at D. 45,1 , which is exactly at the breaking point between Justinian's sexta and septima pars Digestorum. 
As $x_{1}=4$ we have to solve:

(2) $\quad \sum_{i=2}^{7}\left(x_{i}\right)=46$

(2) must be solved for positive integer values of $x_{i}$. As the number of solutions for (2) is large, restrictions have to be made. These restrictions must be of a practical nature. As can be inferred from the text, the number of books in contiguous partes should differ as little as possible. This is the case when the number of books per pars is as close as possible to the average $\mathrm{G}$ (average number of books per pars). Or:

(3) $\mathrm{M}=\min \sum_{i=2}^{7}\left|x_{i}-\mathrm{G}\right|, \mathrm{G}=46 / 6=7^{2 / 3}$.

It is easy to see that, if the set $\left\{x_{i}\right\}, \mathrm{i}=2, \ldots, 7$ contains four occurrences of the number 8 and two of the number 7 , the requirement that the minimal value $M=2^{2 / 3}$ is met $^{105}$. This means there is a total of $\left(\begin{array}{l}6 \\ 2\end{array}\right)=15$ solutions to $(2)$, all of them having the minimum value $M$. As required in the text, the graphical form of the solution has to be in the shape of a "dome", which means that the values of $x_{2}$ and $x_{7}$ are less than $x_{3}$ and $x_{6}$, respectively, or:

(4) $x_{2}<x_{3}$ and $x_{7}<x_{6}^{106}$

There is only one solution that satisfies these restrictions:

$x_{i}=7,8,8,8,8,7$ for $\mathrm{i}=2, \ldots, 7$. This solution hereafter is referred to as $\mathrm{B}$ (base solution).

\section{$3 \quad$ Solution with an additional requirement}

The solution B is symmetric. Therefore:

(5) $x_{i}=x_{9-i}, i=2,3,4$

and also:

(6) $\quad \sum_{i=2}^{4}\left(x_{i}\right)=23$ and hence $\sum_{i=5}^{7}\left(x_{i}\right)=23$.

105 Start with four occurences of 8 and two of 7 . Every other number, other then the 8 and 7 give a higher value of $\mathrm{M}$, given (2). A formal mathematical proof is clearly not necessary.

106 More restrictions are not necessary. There are other restrictions like $x_{3}=x_{4}$ and $x_{6}=x_{5}$. They can be transferred to (4). 
If an additional requirement is made for $x_{5}{ }^{107}$ then $\mathrm{B}$ will not longer be the solution to (2) and the symmetry (5) is also not maintained. Then, for intrinsic reasons (see text), a weaker symmetry (6) is accepted. The restrictions (3) and (4) remain valid. Compared to the original value in $\mathrm{B}$ of $x_{5}(8)$ the requirement is ${ }^{108}$ :

(7) $x_{5} \geq 9$

Starting from B, and the conditions (3) and (4), consider first $x_{5}=9$. The application of (6) gives $x_{6}+x_{7}=14^{109}$. As $x_{7}<x_{6}$, several combinations for $x_{6}$ and $x_{7}$ are possible. Given the requirement (3) (minimization) only $x_{6}=8$ en $x_{7}=6$ suffices and $M=4^{2 / 3}$. For all values $x_{5}>9$ and the corresponding values of $x_{6}$ and $x_{7}$ give higher values for M. Therefore, the required solution is $x_{i}=4,7,8,8,9,8,6$ for $\mathrm{i}=1, \ldots, 7$, which had to be demonstrated.

\section{$4 \quad$ Finally}

I have used a contemporary notation. However, in order to arrive at the solution given above, the argumentation could have been based on numbers alone.

Originally the argumentation may have used other conditions. It is very likely that these can be transformed to those used above.

107 The amount of nine books for the Quinta pars was imperative, as is shown in the main text (p. 513).

108 This is equivalent to $x_{4}<x_{5}$, for $x_{4}=8$.

109 The solution can not be found by compensating $x_{5}$ in the first three values $x_{2}, x_{3}$ and $x_{4}$ because of the requirement under (6). 